УДК 533.9

\title{
GLOBUS-M EXPERIMENTS WITH PRE-DAMAGED TUNGSTEN DIVERTOR
}

\author{
A.N. Novokhatsky', V.K. Gusev ${ }^{1}$, B.Ya. Ber ${ }^{1}$, P.N. Brunkov ${ }^{1}$, V.L. Bukhovets ${ }^{2}$, A.A. Gervash ${ }^{3}$, A.E. Gorodetsky ${ }^{2}$, \\ S.A. Grigoriev ${ }^{3}$, V.E. Kuznetsov ${ }^{3}$, N.V. Litunovsky ${ }^{3}$, A.N. Makhankov ${ }^{3}$, I.V. Mazul ${ }^{3}$, E.E. Mukhin ${ }^{1}$, Yu.V. Petrov ${ }^{1}$, \\ T.V. Rybkina ${ }^{2}$, N.V. Sakharov ${ }^{1}$, R.V. Sokolov ${ }^{1}$, V.N. Tanchuk ${ }^{3}$, S.Yu. Tolstyakov ${ }^{l}$, A.V. Voronin ${ }^{l}$, A.P. Zakharov ${ }^{2}$, \\ R.Kh. Zalavutdinov ${ }^{2}$
}

${ }^{1}$ Ioffe Institute, St.-Petersburg, Russia

${ }^{2}$ A.N. Frumkin Institute of Physical Chemistry and Electrochemistry RAS, Moscow, Russia

${ }^{3}$ D.V. Efremov Institute of Electrophysical Apparatus, St.-Petersburg, Russia

\begin{abstract}
Divertor targets composed of pre-damaged tungsten (W) tiles were prepared and installed at an outer strike point region of a Globus-M lower divertor. An electron beam was used to irradiate the W tiles close to influence of 1000-2000 disruption events in ITER. Providing adequacy of the e-beam thermal load to the real ITER conditions, the pre-damage treatment was simulated by ANSYS Multiphysics software. The W e-beam treatment results in melting of surface layers, shrinkage and fatigue intergranular cracking of the metal, void formation, grain ordering, and decreasing of microhardness. The first test of the pre-damaged $\mathrm{W}$ targets in the Globus-M divertor showed pronounced non-uniform heating caused by plasma disruption events. Temperature field formation may be explained by non-uniform thermal conductivity of the damaged layer or interface between the layer and undamaged bulk structure. One of the most important effects of the pre-damaged $\mathrm{W}$ installation is no significant changes in Globus-M discharge behavior.
\end{abstract}

Key words: spherical tokamak, divertor, first wall, materials science.

DOI: 10.21517/0202-3822-2017-40-4-14-24

\section{ЭКСПЕРИМЕНТЫ С ПРЕДВАРИТЕЛЬНО ОБЛУЧЁННЫМ ВОЛЬФРАМОМ НА ТОКАМАКЕ ГЛОБУС-М}

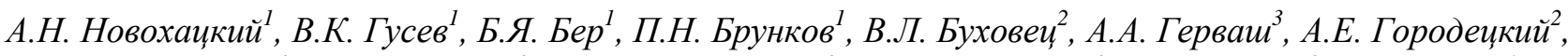 \\ С.А. Григорьев ${ }^{3}$, В.Е. Кузнецов ${ }^{3}$, Н.В. Литуновский, А.Н. Маханьков ${ }^{3}$, И.В. Мазуль ${ }^{3}$, Е.Е. Мухин ${ }^{1}$, \\ Ю.В. Петров ${ }^{1}$, Т.В. Рыбкина ${ }^{2}$, Н.В. Сахаров ${ }^{1}$, Р.В. Соколов ${ }^{1}$, В.Н. Танчук ${ }^{3}$, С.Ю. Толстяков ${ }^{1}$, \\ А.В. Воронин ${ }^{l}$, А.П. Захаров ${ }^{2}$ Р.Х. Залавутдинов
}

${ }^{1}$ ФТИ им. А.Ф. Иоффе РАН, Санкт-Петербург, Россия
${ }^{2}$ Институт физической химии и электрохимии им. А.Н. Фрумкина РАН, Москва, Россия
${ }^{3}$ НИИ электрофизической аппаратуры им. Д.В. Ефремова, Санкт-Петербург, Россия

Диверторные мишени из предварительно облучённых вольфрамовых (W) плиток были изготовлены и установлены на выходе внешней ветви сепаратрисы нижнего дивертора токамака Глобус-М. Для имитации воздействия на мишень 1000 -2000 срывов плазмы, ожидаемых в ИТЭР, применялся электронный пучок. С целью оценки адекватности применяемых в экспериментах методов теплового нагружения вольфрамовых элементов и их соответствия характерным тепловым нагрузкам в реальных условиях токамака ИТЭР была разработана компьютерная модель дивертора на основе программного комплекса ANSYS Multiphysics. В результате воздействия электронного пучка образцы вольфрама претерпели серьёзные структурные изменения: плавление поверхностного слоя, усадку, усталостное межзерновое растрескивание, образование пустот, упорядочение зёрен и уменьшение микротвёрдости. Первые результаты испытаний предварительно облучённых вольфрамовых мишеней в диверторе токамака Глобус-М чётко показывают, что срывы плазмы вызывают неоднородный нагрев поверхности мишени. Образование неоднородного поля температуры свидетельствует о неоднородной теплопроводности повреждённого слоя или зоны между повреждённым слоем и неповреждённым основным материалом плитки. Установка предварительно повреждённой вольфрамовой мишени не внесла значительных изменений в работу Глобуса-М.

Ключевые слова: сферический токамак, дивертор, первая стенка, материаловедение.

\section{INTRODUCTION}

Plasma-wall interaction is main problem for development of ITER plasma facing units (e.g. first wall, divertor, limiters). The most open question connected with the use of $\mathrm{W}$ divertor targets in ITER is the issue of material melting and cracking under transient heat fluxes [1]. Degradation of W surface has been extensively studied all over the world as well in tokamaks as in other plasma sources. From the most important tokamak experiments, it is necessary to pay a special attention to the experiments with $\mathrm{W}$ as a plasma facing armor material in the Joint Euro- 
pean Torus (JET) [2 - 4], ASDEX Upgrade (AUG) [5-7], and Alcator C-Mod [8]. However, none of the existing tokamaks can create heat fluxes equivalent to the fluxes expected in ITER and in tokamak reactors of the next generation. Therefore, along with the tokamaks, there are devices specially designed for modeling impact of such fluxes on the W surface: electron beams [9, 10], linear plasma devices [11], plasma guns [12-16], plasma focus machines [17, 18]. Currently, the most adequate ITER-like plasma-wall interaction can be modeled in real tokamaks contained $\mathrm{W}$ tiles preliminary irradiated (damaged) in alternative high heat flux machines.

At the existing machines, the investigation of the plasma interaction with preliminary melted (damaged) W layers must be concentrated on the study of W layer properties, layer structure dynamics, flaking formation, and tokamak plasma parameters.

In the experiments described in the paper, several $\mathrm{W}$ mock-ups were damaged using an electron beam facility (Tsefey-M, Efremov Institute) [19] at a load compared with power deposited during 1000 -2000 disruption events in ITER. Experiments with W mock-ups exposed to plasma jet of a coaxial gun (Ioffe Institute) have been presented in [20]. The pre-damaged W mock-ups were installed at an outer strike point region of a Globus-M lower divertor with a maximal deposited heat flux reaching $2.5 \mathrm{MW} / \mathrm{m}^{2}$ [21]. Providing adequacy of the e-beam thermal load to the real ITER conditions, the pre-damage treatment was simulated by ANSYS Multiphysics software. The present work was guided to the experimental study of cyclic action of the high heat fluxes of the e-beam and tokamak plasma on W tiles designed, currently, for an ITER divertor.

\section{MANUFACTURING OF W DIVERTOR TARGET MOCK-UPS}

Several hot-rolled W mock-ups of ITER divertor Dome armor were designed and manufactured in Efremov Institute [22]. Chemical composition (wt. \%) of the $\mathrm{W}$ is the following: $\mathrm{C}-0.004, \mathrm{~N}-0.002, \mathrm{O}-0.008, \mathrm{Si}-$ $0.005, \mathrm{Fe}-0.005, \mathrm{Ni}-0.001$. The mock-ups consist of $\mathrm{W} / \mathrm{Cu}$ tiles $(8 \mathrm{~mm} \mathrm{~W}+1 \mathrm{~mm}$ oxygen free high conductive (OFHC) $\mathrm{Cu}$ ) with a planar size of $23.9 \times 20.5 \mathrm{~mm}$ that were brazed to a $2 \mathrm{~mm}$ thick $\mathrm{Cu}$ substrate in vacuum by a Stemet ${ }^{\circledR} 1108$ filler (Cubase $\mathrm{Sn}_{12} \mathrm{In}_{7} \mathrm{Ni}_{3}$, wt. \%). The filler was approved for brazing the armor of the ITER Divertor Dome [23] with the following parameters: $T=900{ }^{\circ} \mathrm{C}, t=300 \mathrm{~s}, P \sim 5 \cdot 10^{-4} \mathrm{~Pa}$. Special fixture and rigs for proper armor fixation and clamping were developed and used.

All armoring tiles were produced by JSC POLEMA from the same batch of $\mathrm{W}-\mathrm{Cu}$ plates, which should be used by Efremov Institute for production of the armor for the Divertor Dome. The only difference was thickness of the $\mathrm{Cu}$ substrate, which was machined from standard $2 \mathrm{~mm}$ down to $1 \mathrm{~mm}$ to fit the thickness of a surrounding graphite armor of the Globus-M divertor.

One intact mock up (Fig. 1, a) was installed in the divertor as a reference sample. Two other mock-ups were brazed onto the $\mathrm{Cu}$ substrate and then to an actively cooled $\mathrm{CuCrZr}$ substrate. The assemblage obtained in such way (Fig. 2) was used for preliminary e-beam irradiation with loading parameters sufficient for multiple remelting of the surface (as a simulation of ELMs). Two trapezoidal plasma-facing pieces of the armor assembling with a thin $\mathrm{CuCrZr}$ layer were carved out by Electrical Discharge Machining to install into Globus-M outer strike-point of the lower divertor region.
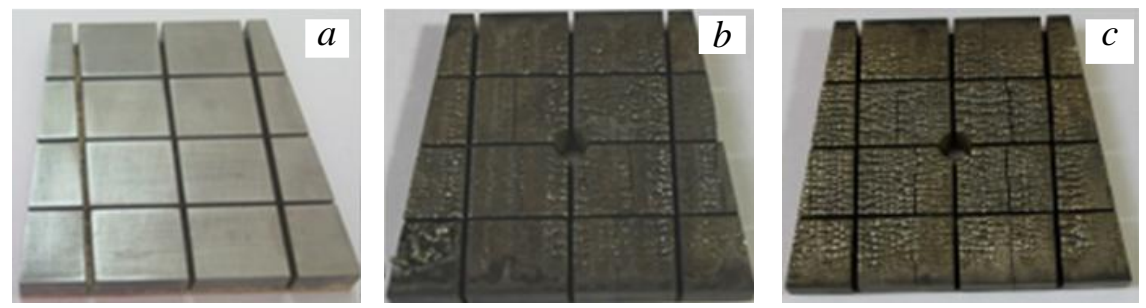

Fig. 1. W mock ups: initial (a); after 1000 e-beam cycles $(b)$; after 2000 e-beam cycles $(c)$

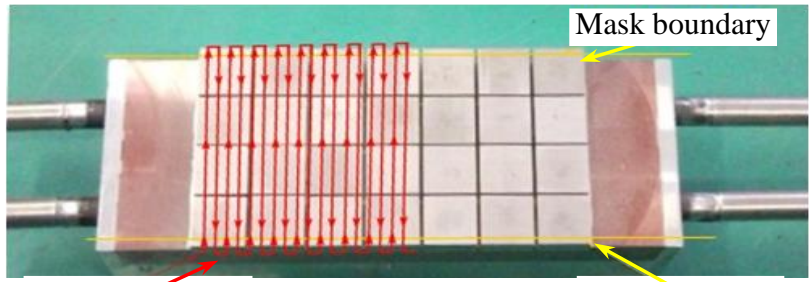

Mask boundary

Three cross-sections of the initial and damaged mock-ups were prepared by mechanical grinding and polishing with subsequent mild etching in a solution consisted of $1 \mathrm{~g} \mathrm{NaOH}, 3.5 \mathrm{~g} \mathrm{~K}{ }_{3} \mathrm{Fe}(\mathrm{CN})_{6}$ and $75 \mathrm{ml}_{2} \mathrm{O}$. 


\section{ELECTRON BEAM TREATMENT OF W MOCK-UPS}

The actively cooled $\mathrm{W}$ mock ups (water at $20^{\circ} \mathrm{C}$, mass flow rate $0.675 \mathrm{~kg} / \mathrm{s}$ ) were pre-damaged in the e-beam facility Tsefey-M (the coaxial accelerator with power of $200 \mathrm{~kW}$ and accelerating voltage of $40 \mathrm{kV}$ ). The duration of one vertical scanning raster was of $9 \cdot 10^{-2} \mathrm{~s}$. A vertical scanning cycle train consists of 36 lines. The duration one complete cycle was equal $3.2 \mathrm{~s}$ whereas e-beam spot exposure (without pauses) covered of $18 \mu \mathrm{s} \cdot 2500 \cdot 36=1.62 \mathrm{~s}$. Each cycle of melting was finished when a total mock-up area was covered (scanned by e-beam melts). Two W mock-ups melted by e-beam during 1000 and 2000 cycles were performed (see Fig. 1, b, c).

The e-beam of $12 \mathrm{~mm}$ in diameter (at FWHM) provides maximum heat flux density $q=1680 \mathrm{MW} / \mathrm{m}^{2}$ during $t_{\text {pulse }}=18 \mu \mathrm{s}$. The one-pulse e-beam footprints overlapped in the vertical scanning raster with a density of 2490 spots per $70 \mathrm{~mm}$ and distance between neighboring centers of $0.03 \mathrm{~mm}$. The spots practically superimpose on one another for $200-400$ pulses that increased the time of $\mathrm{W}$ irradiation up to $t_{\text {trans }}=3.6-7.2 \mathrm{~ms}$.

The influence of different nonstationary heat loads can be assessed in terms of the «heat flux factor» $F_{\mathrm{HF}}$ [24], which is proportional to the maximum surface temperature rise $(T)$, expected in response to a given transient heat pulse:

$$
F_{\mathrm{HF}}=0.7 q t_{\text {trans }}^{1 / 2} \text {. }
$$

For melting the $\mathrm{W}$ surface, taking into consideration the melting temperature $T_{\text {melt }}=3695 \mathrm{~K}$ [25], a value of the $F_{\mathrm{HF}}$ is to be $>50 \mathrm{MJ} \cdot \mathrm{m}^{-2} \cdot \mathrm{s}^{-1 / 2}$ and for the ELM-events in ITER the $F_{\mathrm{HF}}$ is $(77-123) \mathrm{MJ} \cdot \mathrm{m}^{-2} \cdot \mathrm{s}^{-1 / 2}[1]$. As follows from eq. (1), the $F_{\mathrm{HF}}$ for Tsefey-M is equal to $70 \mathrm{MJ} \cdot \mathrm{m}^{-2} \cdot \mathrm{s}^{-1 / 2}$.

After the e-beam treatment the damaged mock-ups were analyzed using scanning electron microscopy (SEM), electron probe microanalysis (EPMA), $x$-ray diffraction (XRD), and optical microscopy (OM).

\section{TEMPERATURE MAP SIMULATION}

A surface temperature map and temperature gradient distributions were simulated in ANSYS Multiphysics software [25] with the use of W mock-up finite-element (FE) model (Fig. 3). A physical model of the tile surface heating included re-radiation losses from the heated surface as well as a total loss in the re-melting process and evaporation. The FE model consists of 54266 elements. A thermal mass, solid, Brick 8-node 70 (also known as Solid70 within ANSYS) element is the basic type of the model elements applied for the transient thermal analysis. The 3D elements having in-plane thermal conduction capability SHELL57, SURF152 and group of previously assembled ANSYS elements generated as a superelement MATRIX50 were included in the 3D ANSYS model to simulate the radiative heat exchange. The e-beam parameters assumed are as follows: total power of $195 \mathrm{~kW}$, pulse duration of $18 \mu \mathrm{s}$, maximum heat flux $q=1680 \mathrm{MW} / \mathrm{m}^{2}$, Gaussian beam profile with FWHM of $12 \mathrm{~mm}$, absorption of 70\% from the incident beam energy (Fig. 4).

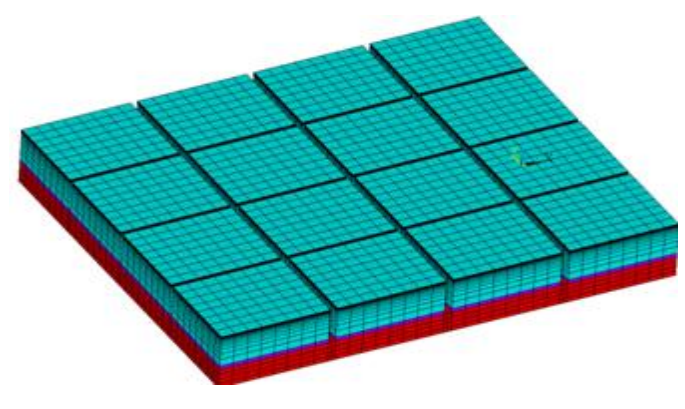

Fig. 3. General view of the model with the calculation mesh: number of elements $N=54266$

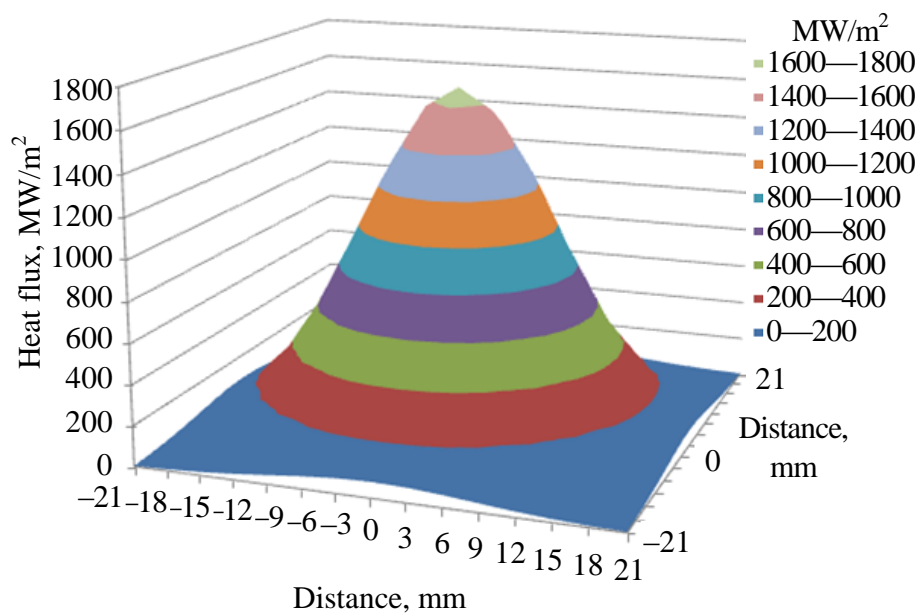

Fig. 4. Power profile of the scanning e-beam 
Eighteen vertical passages of the e-beam, corresponding to a half of the total thermal loading (see zone 1 in Fig. 2, $b$ ), were simulated. The temperature maps are given for two locations of the e-beam center: the upper and the lower footprints of the second row corresponding to $\tau=0.3208 \mathrm{~s}$ and $\tau=0.3658 \mathrm{~s}$ (Fig. 5).
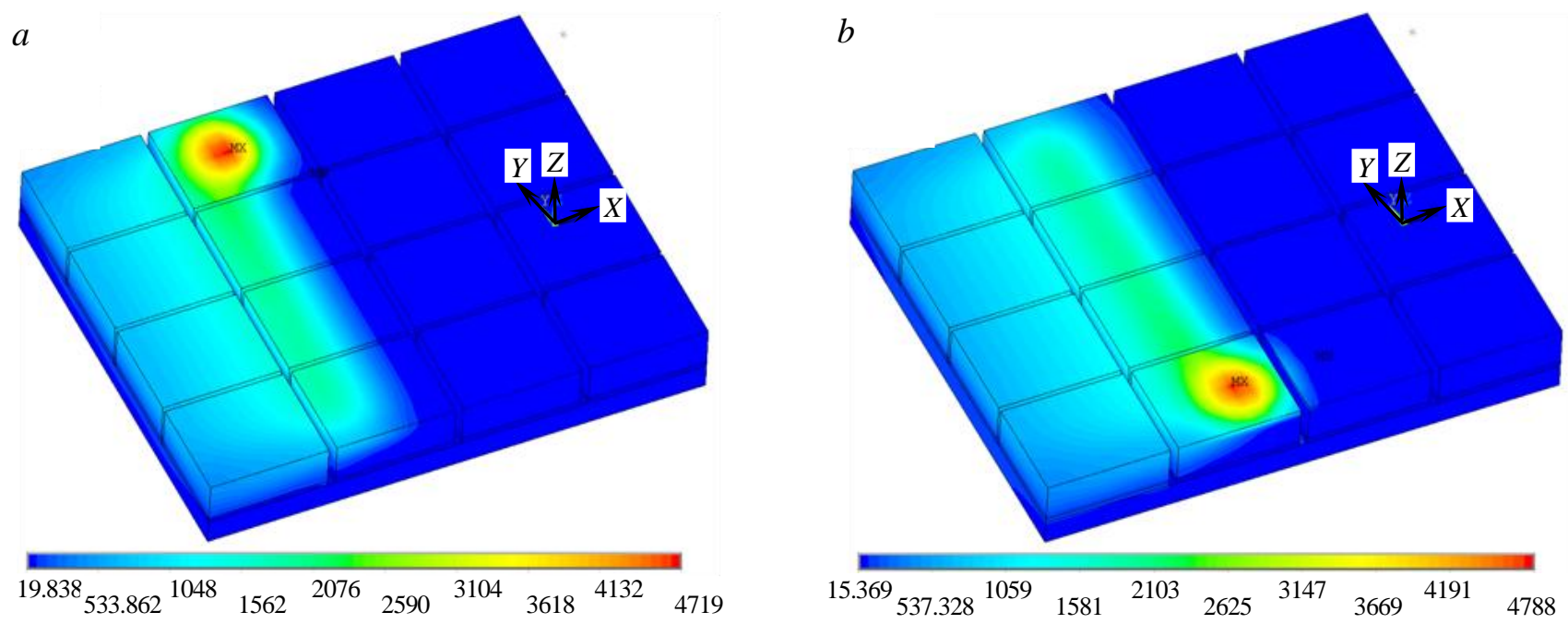

Fig. 5. Temperature distributions over $\mathrm{W}$ tiles loaded by scanning e-beam at times: $\tau=0.3208 \mathrm{~s}(a), \tau=0.3658 \mathrm{~s}(b)$

The numerical simulation has shown that surface temperature exceeded the $\mathrm{W}$ melting temperature. Thus, the e-beam scanning resulted in the melting tracks at the W surface. Fig. 6 shows the simulated profile of the $\mathrm{W}$ tile surface melting with a maximal depth of $\sim 0.13 \mathrm{~mm}$.

During one passage of the e-beam (1.6 s, without pauses) the whole mock-up surface was re-melted. Since the purpose of the experiment was to re-melt the surface layer, the Gaussian beam choice was reasonable, because an uniform e-beam of the same power does not melt the $\mathrm{W}$ surface during $1.6 \mathrm{~s}$ $\left(F_{\mathrm{HF}}=\sim 10 \mathrm{MJ} \cdot \mathrm{m}^{-2} \cdot \mathrm{s}^{-1 / 2}\right)$. On the other hand, signifi-

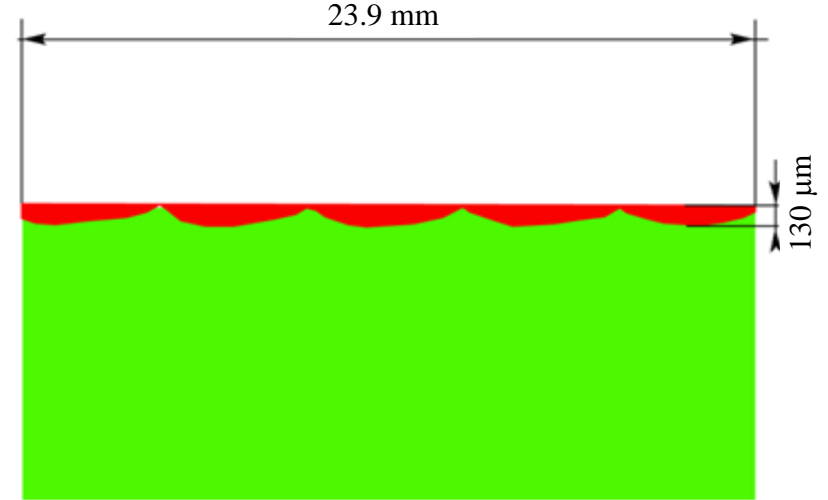

Fig. 6. Profile of $\mathrm{W}$ tile surface melting obtained by the numerical simulation

cant temperature gradients in the heated spot and sequential melting/crystallization cycles of the local zones result in multiple microcracks on the treated surface.

\section{MORPHOLOGY, CHEMICAL COMPOSITION AND STRUCTURE OF THE PRE-DAMAGED W SURFACE}

SEM analyses combined with EPMA (an energy-dispersive spectroscopy (EDS)) of the W surfaces after the e-beam treatment have showed that the surfaces were roughened and sheathed with a net of shrinkage cracks. On the surface one could see the traces of melting (Fig. 7, a). The irradiated W surface was covered by oxide and carbide films. After 2000 cycles the width of cracks increased and particles (with sizes $<10 \mu \mathrm{m}$ ) located inside the cracks contained traces of $\mathrm{C}, \mathrm{O}, \mathrm{Fe}$, and $\mathrm{Cu}(\mathrm{Fig} .7, b)$.
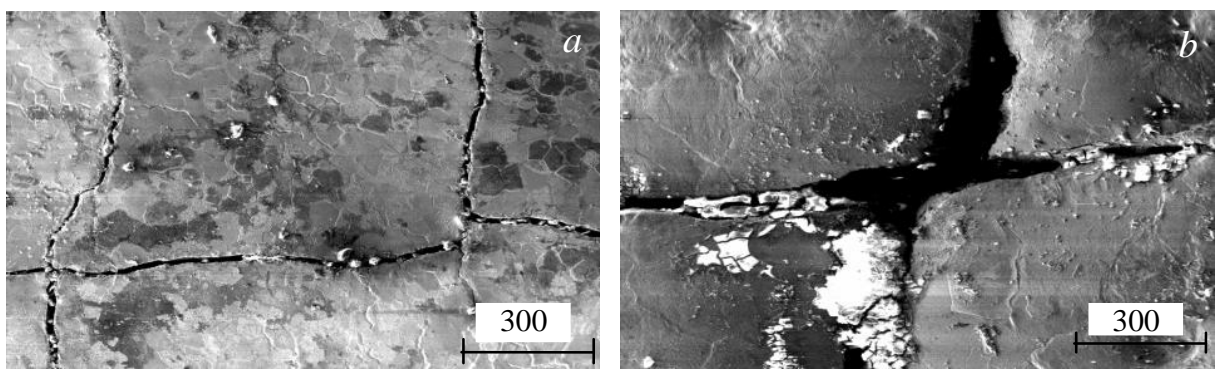

Fig. 7. Micrographs of $\mathrm{W}$ tile surfaces after e-beam treatment: $a-1000$ cycles; $b-2000$ cycles 
Crystalline structure of the surface layers was analyzed by conventional XRD using $\mathrm{Cu} K_{\alpha}$ radiation at Bragg angles $2 \theta=5-140^{\circ}$ (Fig. 8). After 1000 and 2000 cycles the intensity of the W(110) and W(321) peaks at the angle $2 \theta=40.3^{\circ}$ (interplanar spacing $\left.\mathrm{d}=0.2238 \mathrm{~nm}\right)$ and $2 \theta=131.2^{\circ}(d=0.08465 \mathrm{~nm})$ increased and the integral breadth of the diffraction lines decreased to $0.5^{\circ}$ to $0.2^{\circ}$, respectively. Using the Scherrer equation to a certain average crystallite size [27], we found that the crystallites (regions of coherent scattering) were of $40 \mathrm{~nm}$ in [110] and [321] directions (Fig. 8, $a, b$, curves 2 and 3). The broad $\mathrm{W}(321)$ reflection from the initial sample transformed to clearly resolved $K_{\alpha}$-doublet. The full resolving of the doublet $2 \theta=131.2-131.9^{\circ}$ (Fig. 8, $b$, curves 2 and 3) is observed, usually, if the metal crystallite sizes exceed $100 \mathrm{~nm}$ [28].
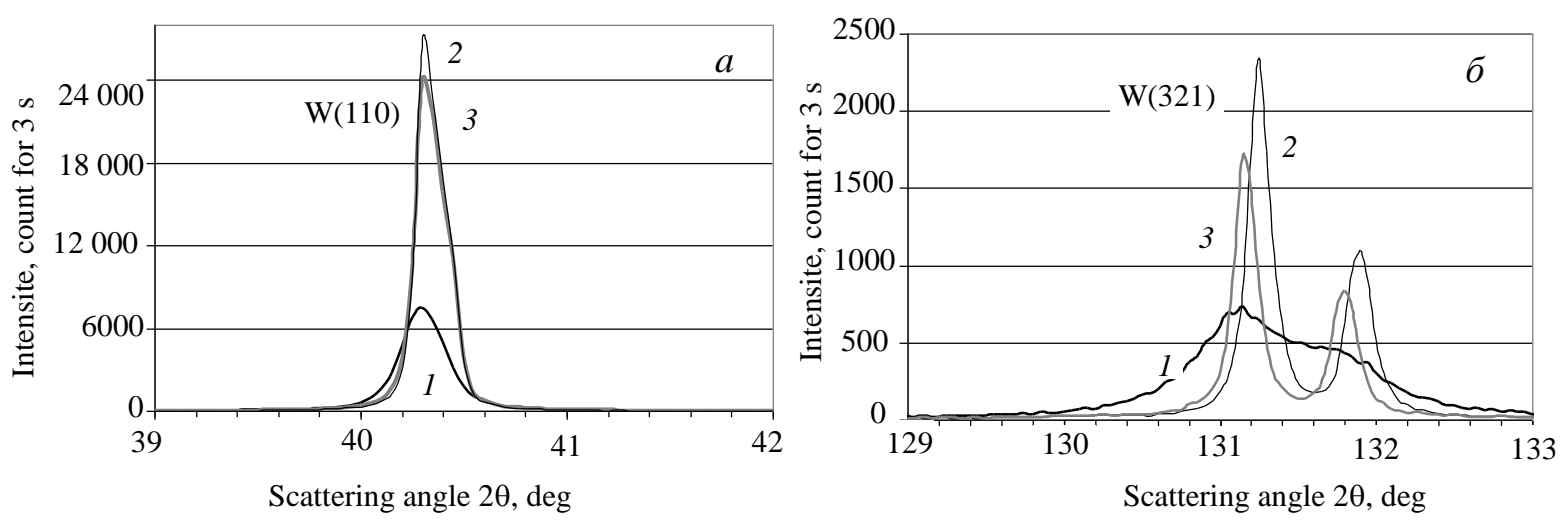

Fig. 8. W(110) (a), W(220) (b) XRD patterns for the initial (1) and e-beam irradiated W sample: 2 - 1000 cycles; $3-2000$ cycles

As follows from the analysis of the W(110), W(220) (is not shown in Fig. 8) and W(321) peaks, a surface layer of $2.5 \mu \mathrm{m}$ in thick underwent manifold re-crystallizations during 1000 and 2000 cycles and a preferred texture with an axis of [110] normal to the surface was formed. It should be noted that broadening of W(110) and $\mathrm{W}(220)$ reflexes $\left(\Delta 2 \theta=0.2^{\circ}\right)$ had the same value in the thermal loaded samples. It indicates that lattice strains were absent in the analyzed irradiated surface layers. At such limited texture the rise of the W(321) peak intensity is connected with a moderate tilt angle $\left(19^{\circ}\right)$ between $\mathrm{W}(110)$ and $\mathrm{W}(321)$ planes of the W lattice.

An important information about the thermal loading was obtained by OM. Analysis of the cross-section of the W mock-up treated by 1000 cycles revealed that in the initial flat surface a weakly wavy relief with roughness about $100 \mu \mathrm{m}$ was formed. In a surface layer of $0.15-0.2 \mathrm{~mm}$ thick (Fig. 9, $a$ ) a grain size exceeded $100 \mu \mathrm{m}$ (one grain can involve several coherently diffracted crystallites). The grains had moderately smooth boundaries that strongly differed from $10-20 \mu \mathrm{m}$ grains of indented boundaries in the initial samples.

$a$

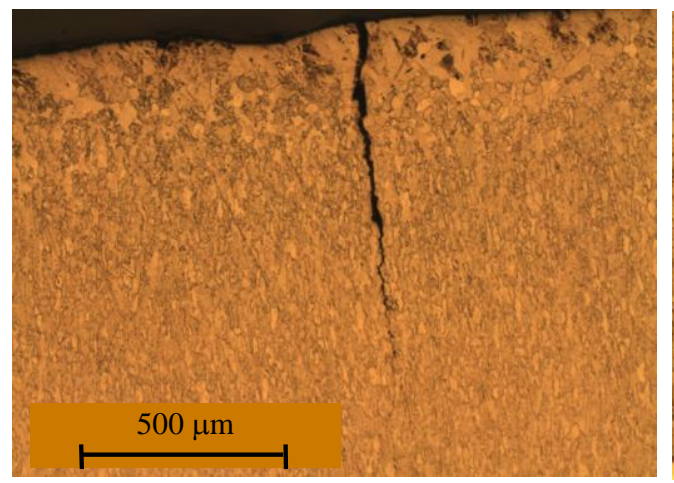

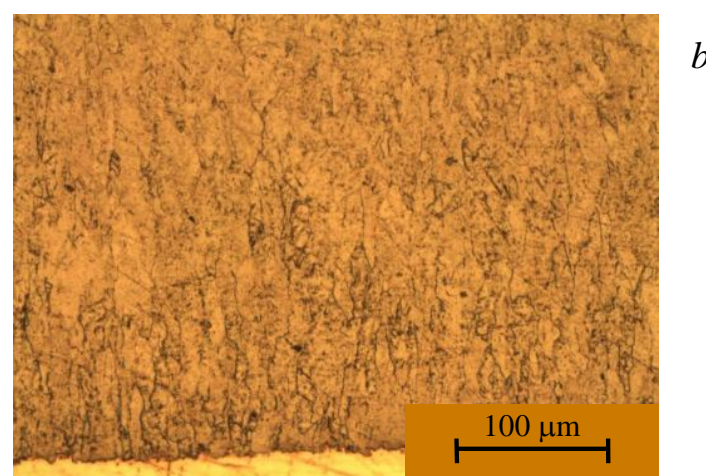

Fig. 9. Microstructure $(\mathrm{OM})$ of polished and etched cross-section of the W mock-up irradiated by 1000 cycles: $a$ - top of the sample with a remelting layer of $0.25 \mathrm{~mm}$ depth; $b$ - lower fraction of $\mathrm{W} / \mathrm{Cu}$ interface with partly ordering grains

The obtained data allow concluding that $\mathrm{W}$ surface layer was subjected to multiple melting and crystallization that were accompanied by relief development, certain crystallite size increasing and texture improvement.

A tendency toward ordering grains was observed throughout the thickness of the $\mathrm{W}$ layer up to the $\mathrm{Cu}$ substrate (see Fig. 9, $b$ ). The difference between arbitrary and regulated grain orientations at a depth of $6 \mathrm{~mm}$ in the initial and treated by 1000 cycles samples is shown in Fig. $10 a, b$. 
$a$

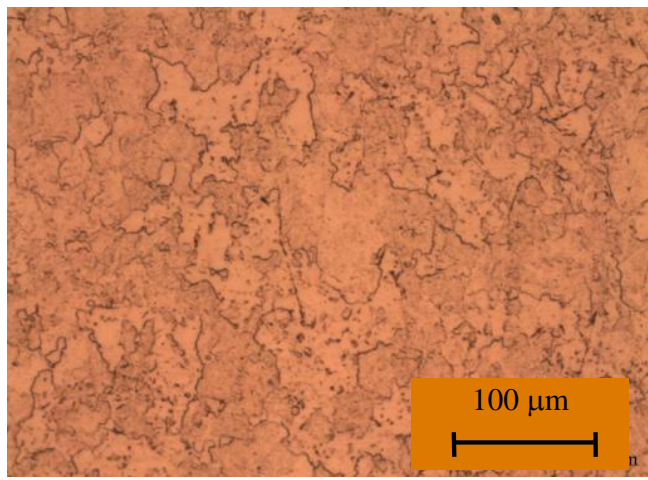

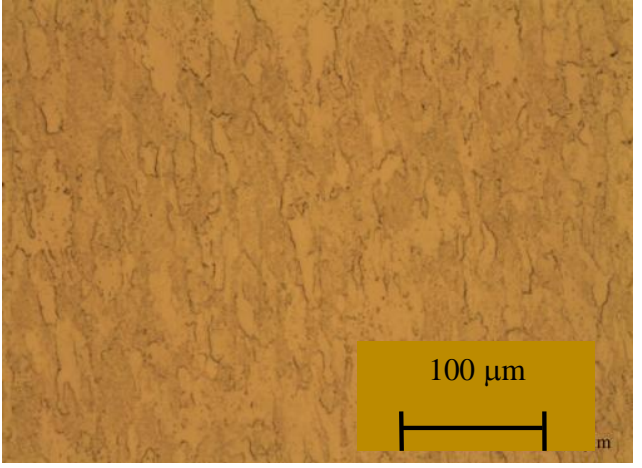

Fig. 10. Microstructure (OM) of polished and etched cross-section of the $\mathrm{W}$ mock-up at a distance of 6 mm from the surface: $a-$ initial sample; $b$ - sample after 1000 cycles

After 2000 heating cycles the surface roughness increased up to $0.15 \mathrm{~mm}$. The re-melted and damaged layer thickness was in the range of 120-240 $\mu \mathrm{m}$ (Fig. 11,a). The size of the recrystallized grains observed just under the damaged layer reached $200 \mu \mathrm{m}$. Ordering grains and ordering intergranular boundaries were observed everywhere over metal cross-section (Fig. 11,b).
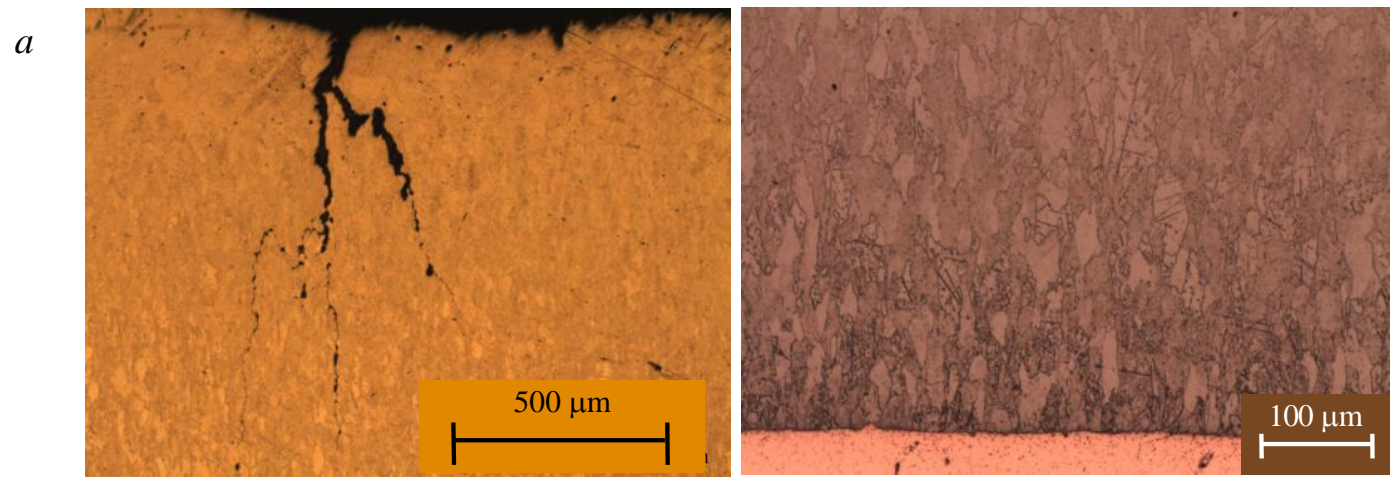

$b$

Fig. 11. Optical images of $\mathrm{W}$ mock-up cross-section after 2000 cycles: $a$ - top of the sample with a re-melting layer of $0.25 \mathrm{~mm}$ depth and branchy cracks of $1 \mathrm{~mm}$ length; $b$ - bottom of the sample with recrystallied and ordered grains on the interface $\mathrm{W} / \mathrm{Cu}$

Thickness of the strongly modified layer was estimated from HV microhardness measurements performed on the polished cross-section of the treated (e-beam 2000 cycles) and untreated samples. The measurements were made at a loaded force of $50 \mathrm{gf}$ (gram-force) [29]. The microhardness decreased from $5 \mathrm{GPa}$ (initial sample) to $3 \mathrm{GPa}$ (after 2000 cycles) up to the depth of $4 \mathrm{~mm} \mathrm{[30].} \mathrm{At} \mathrm{approaching} \mathrm{to} \mathrm{Cu}$ substrate the microhardness gradually increased up to initial value of $5 \mathrm{GPa}$. At the same time ordering of grain orientations was followed to the $\mathrm{Cu}$ substrate.

These data can be explained by $\mathrm{W}$ recrystallization occurred in all parts of the treated mock up during e-beam loading. It is known that the $\mathrm{W}$ recrystallization takes place at $T>1200^{\circ} \mathrm{C}$ [25].

As a result of repeated recrystallization the total length of intergrain boundaries reduced, and this may be responsible for decreasing of the microhardness.

The cracks, which were seen in the SEM, clearly recorded at cross-section of mock ups. After 1000 cycles a number of fatigue cracks at a length of $1 \mathrm{~mm}$ was about unity. A crack length and width were $1-3 \mathrm{~mm}$ and dozens $\mu \mathrm{m}$, respectively (see Fig. 9, $a$ ). Some cracks extended to the $\mathrm{Cu}$ substrate, i.e. they propagated up to a depth of $\sim 8 \mathrm{~mm}[30]$.

During thermocycling a linearity growing fatigue intergranular crack could branch out and generated voids in stress fields (see Fig. 11,a). After 2000 cycles, along with intergranular cracking the processes of recrystallizing and ordering of the grains took place in the whole mock-up cross-section (see Fig. 11, $b$ ). The fatigue cracks were initiated at a depth of $0.3 \mathrm{~mm}$ from the surface due to significant local heating and decreasing of intergranular strength. In the cross-sections such cracks had different branched forms.

The cracks could cause thermal isolation of the individual cells that may lead to non-uniform heating, increasing grain sizes at re-solidification and, as a result, roughening of the upper layers [31, 32]. 
It is known that $\mathrm{W}$ becomes brittle at temperature decreasing to $950-1150^{\circ} \mathrm{C}$ [30]. During scanning of mock-up surface by e-beam, when in sme local regions the temperature exceeded $1200^{\circ} \mathrm{C}$, in neighbouring regions it decreased below $1000{ }^{\circ} \mathrm{C}$. It is likely a net of cracks was able to form in the mock ups during cooling to embrittlement temperature.

The analyses of the W mock-ups showed that e-beam treatment resulted in melting of surface layers, shrinkage and fatigue intergranular cracking of the metal, void formation, grain ordering in the direction normal to the surface for the whole metal, and decreasing of microhardness. The obtained data may indicate $\mathrm{W}$ recrystallization that usually occurs at $T>1200{ }^{\circ} \mathrm{C}$. The W/Cu interface was also disturbed in some places.

\section{TOKAMAK EXPERIMENTS WITH PRE-DAMAGED ITER-LIKE W MOCK-UPS}

Globus-M is a compact spherical tokamak with toroidal magnetic field $B_{\mathrm{T}}=0.4 \mathrm{~T}$, plasma current $I_{\mathrm{p}}=115-250 \mathrm{kA}$, major radius $R \leq 0.36 \mathrm{~m}$, minor radius $a \leq 0.24 \mathrm{~m}$ provided with NBI and IC auxiliary heating systems [33]. Small ratio of the first wall area to plasma volume results in considerable power density loads to the first wall. Almost $90 \%$ of the inner vacuum vessel surface area, directly facing the plasma, is covered by graphite tiles doped with 2 at.\% Ti and $0.3-0.7$ at.\% Si (RGTi) [34, 35].

One sector of the regular Globus-M RGTi divertor

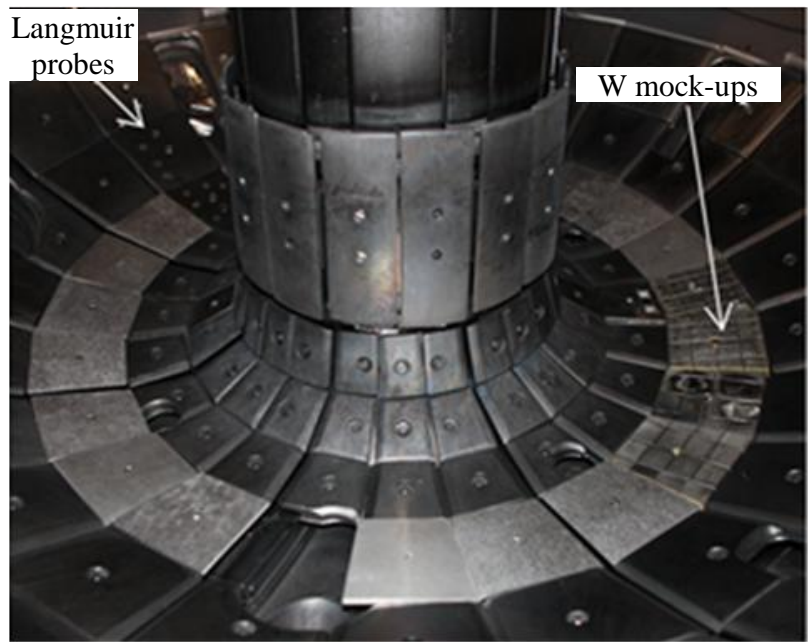

Fig. 12. W mock ups installed in lower divertor of the Globus-M tokamak tiles were replaced with the $\mathrm{W}$ tiles. The sector consists of the pre-damaged ITER-like W mock ups and 18 plates of $3 \mathrm{~mm} \mathrm{~W}$ sheet, with radial dimensions of $\sim 83 \mathrm{~mm}$ each of them (Fig. 12). No significant changes in tokamak plasma behavior caused by the pre-damaged $\mathrm{W}$ mock-ups were observed.

The heat flux distribution at the divertor plate was measured by video cameras Optronics CR Series sensitive in visible and Flir SC 7300M MWR MCT sensitive in infrared $(3-5 \mu \mathrm{m})$ ranges. The cameras provided pictures of the Globus divertor plates with spatial resolution of about $2 \mathrm{~mm}$, repetition rate of $100-600$ frames per second and exposure time of $50-500 \mu \mathrm{s}$. The damaged tiles were analyzed during and right after the discharge termination by both the infrared and visible cameras in lower $X$-point divertor configuration with and without neutral beam heating. Fig. 13 demonstrates that right after disruption the visible luminescence of the $\mathrm{W}$ tile surface was the same for pre-treated and untreated $\mathrm{W}$ tiles that may be explained by luminescence of heated dust. Then, the untreated $\mathrm{W}$ tiles stopped lightning just after the discharge termination. On the contrary, the heat removal from the bulk of the tiles damaged by 2000 e-beam cycles was obstructed by the loose layer formation and led to the surface
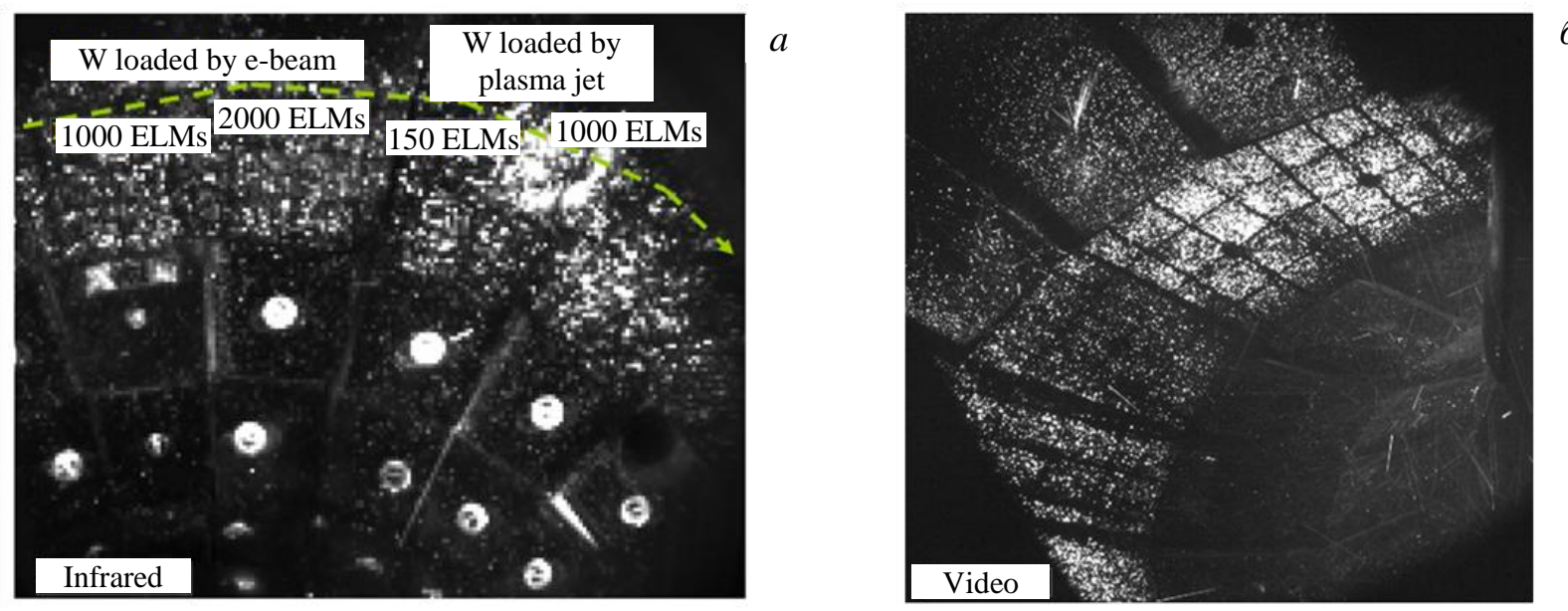

$\sigma$

Fig. 13. Infrared $(a)$ and Video $(b)$ frames of the Globus-M divertor after current disruption (\#32702) 
temperature increase (see details in [36, 37]). Through $5 \mathrm{~ms}$ after the discharge termination, the infrared camera has shown a higher temperature of the tile pre-damaged by 2000 e-beam cycles (Fig. 14).

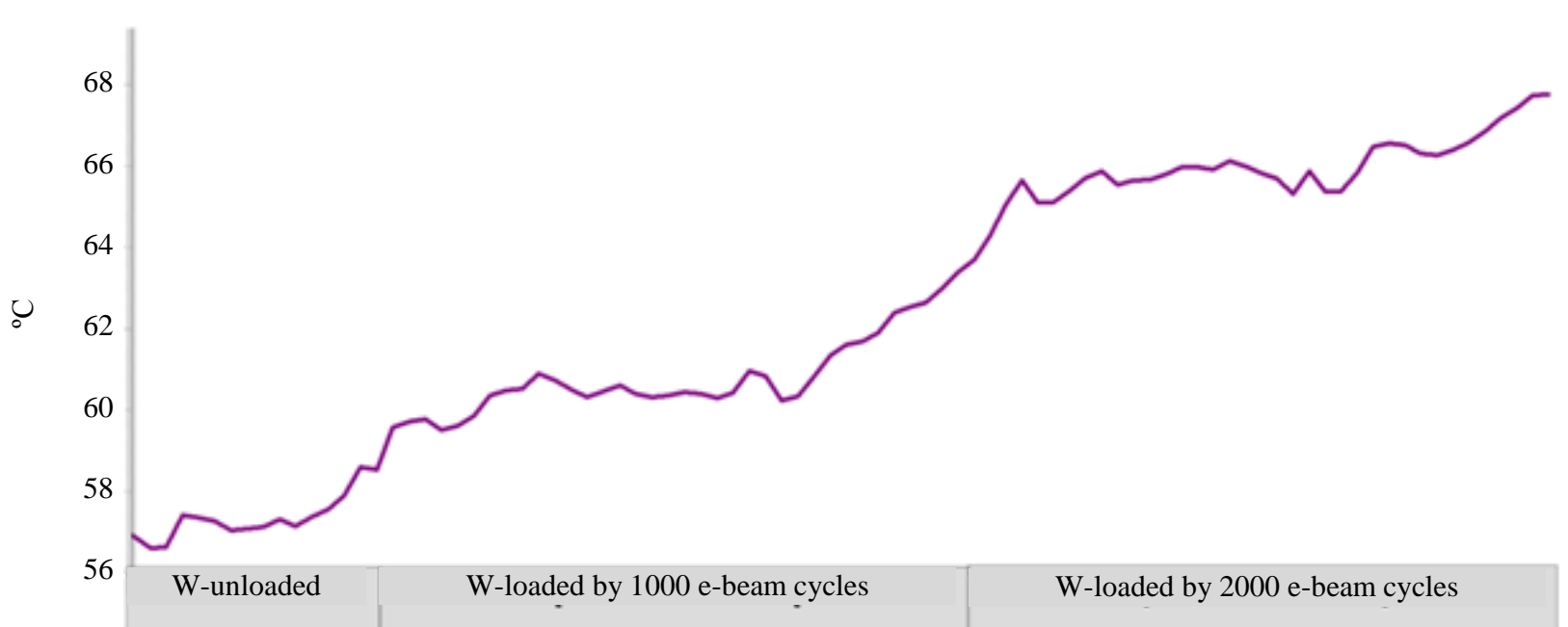

Fig. 14. Local surface temperature distributions along dashed line in Fig. 13 (top). From left to right: W tiles unloaded, W tiles previously loaded by 1000 and 2000 e-beam cycles; the measurements were taken $5 \mathrm{~ms}$ after the shot end

In addition to the e-beam processing, the pre-damaging was also carried out with the use of plasma gun, which was described in $[36,37]$. The e-beam loading used in the experiment caused re-melting of the tungsten surface layer and changes of the surface properties.

\section{CONCLUSIONS}

Analysis of plasma-wall interaction with pre-damaged ITER like tungsten tiles was made in the Globus-M lower divertor and compared with behavior of intact $\mathrm{W}$ tiles. The pre-damaging was done in electron beam facility Tsefey-M. The e-beam treatment can realize the required heat loading during the time frame, but it does not cause sputtering, ion implantation and gas retention.

The analyses of the $\mathrm{W}$ mock-ups showed that e-beam treatment resulted in melting of surface layers, shrinkage and fatigue intergranular cracking of the metal, void formation, grain ordering in the direction normal to the surface for the whole metal, and decreasing of microhardness. The obtained data may indicate $\mathrm{W}$ recrystallization that usually occurs at $T>1200^{\circ} \mathrm{C}$.

The infrared camera showed increasing of temperature field at the mock ups damaged by e-beam due to the effect of a loose layer formation, which decreases the heat conductivity of the tiles and prevents the heat removal from the tile surface. In spite of hardly damaged W mock ups usage in Globus-M divertor, no sensitive influence on the discharge conditions was observed including radiation losses, loop voltage, and plasma current.

\section{ACKNOWLEDGEMENT}

The work is performed on the Unique Scientific Facility «Spherical tokamak Globus-M», which is incorporated in the Federal Joint Research Center «Material science and characterization in advanced technology», with financial support by the Ministry of Education and Science of the Russian Federation (Agreement № 14.621.21.0013, 28.18.2017, id RFMEFI62117X0018).

\section{REFERENCES}

1. Pitts R.A. et al. A full tungsten divertor for ITER: physics issues and design status. - J. Nucl. Mater., 2013, vol. 438, pp. 48 - 56; http://dx.doi.org/10.1016/j.jnucmat.2013.01.008.

2. Romanelli F. et al. Overview of the JET results with the ITER-like wall. — Nucl. Fusion, 2013, vol. 53, p. 104002; doi:10.1088/0029-5515/53/10/104002. 
3. Lorne H. et al. The JET ITER-like wall experiment: first results and lessons for ITER. — Fusion Engineering and Design, 2013, vol. 88, pp. 434-439.

4. Likonen J. et al. First results and surface analysis strategy for plasma-facing components after JET operation with the ITER-like wall. - Phys. Scr., 2014, vol. T159, p. 014016.

5. Gruber O. et al. Compatibility of ITER scenarios with full tungsten wall in ASDEX upgrade. — Nucl. Fusion, 2009, vol. 49, p. 115014.

6. Herrmann A. et al. A solid tungsten divertor for ASDEX upgrade. - Phys. Scr., 2011, vol. T145, p. 014068; doi: 10.1088/0031-8949/2011/T145/014068.

7. Neu R. et al. Overview on plasma operation with a full tungsten wall in ASDEX upgrade. — J. Nucl. Mater., 2013, vol. 438, pp. S34-S41.

8. Barnard H., Lipschultz B., Whyte D. — J. Nucl. Mater., 2011, vol. 415 (Suppl.1), pp. S301—S304.

9. Shoshin A. et al. Plasma-surface interaction during ITER type 1 ELMs: comparison of simulation with QSPA KH-50 and the GOL-3 facilities. - Fusion Sci. Technol., 2011, vol. 59, p. 57.

10. Loewenhoff Th. et al. ITER-W monoblocks under high pulse number transient heat loads at high temperature. - J. Nucl. Mater., 2015, vol. 463, pp. 202-205.

11. De Temmerman G. et al. ELM simulation experiments on pilot-psi using simultaneous high flux plasma and transient heat/particle. - Nucl. Fusion, 2011, vol. 51, p. 073008.

12. Garkusha E. et al. - J. Nucl. Mater., 2011, vol. 415, p. S65.

13. Safronov V.M. et al. - Probl. At. Sci. Technol. Ser. Plasma Phys., 2010, vol. 16 (6), p. 51.

14. Voronin A.V. et al. Irradiation of different type of tungsten by plasma jet. - Technical Physics, 2014, vol. 59 (3), pp. 346-352; http://link.springer.com/article/10.1134/S1063784214030025.

15. Voronin A.V. Degradation of tungsten under the action of a plasma Jet. ISSN 1063_7842. — Technical Physics, 2014, vol. 59 (7), pp. 981-988; (C) Pleiades Publishing, Ltd., 2014; original russian text (C) 2014, published in Zhurnal Tekhnicheskoi Fiziki, 2014, vol. 84 (7), pp. 36 - 43; http://link.springer.com/article/10.1134/S1063784214070275.

16. Voronin A.V. et al. Study of tungsten at cyclic interaction with jet of plasma gun. - Technical Physics Letters, 2014, vol. 40 (24); original russian text published in Pis'ma v Zhurnal Tekhnicheskoi Fiziki, 2014, vol. 40 (24).

17. Scholz M. et al. Progress in MJ plasma focus research at IPPLM. - Nukleonika, 2012, vol. 57(2), pp. $183-188$.

18. Pimenov V.N. et al. Damage and modification of materials produced by pulsed ion and plasma streams in dense plasma focus device. - Nukleonika, 2008, vol. 53 (3), pp. 111-121.

19. Gagen-torn V.K. et al. — In: Proc. of 18th SOFT. Karlsruhe, 1994, p. 363.

20. Voronin A.V. et al. — Technical Physics, 2013, vol. 58 (8), pp. 1122-1128; C Pleiades Publishing, Ltd., 2013.

21. Gusev V.K. et al. Review of Globus-M spherical tokamak results. — Nucl. Fusion, 2015, vol. 55, p. 104016 (15 p).

22. Novohatsky A.N. et al. — In: Proc. of 40th EPS Conf. on Plasma Phys. Helsinki, 2013, P2.119.

23. Litunovsky N.V. et al. Dev. of armoring technique for ITER divertor dome. - FE\&D 2011, vol. 86, p. 1749.

24. Hirai T., Pintsuk G. - Fus. Eng. and Des., 2007, vol. 82, p. 389.

25. Ansys User's Guide, Release 14.0. November 2013.

26. Balzar D. - J. Res. Natl. Inst. Stand. Technol., 1993, vol. 98, p. 321.

27. Alexander L., Klug H.P. Determination of crystallite size with the $X$-Ray spectrometer. — J. of Applied Physics, 1950, vol. 21, p. 137; doi: 10.1063/1.1699612.

28. Franco A.R. et al. The use of a vickers indenter in depth sensing indentation for measuring elastic modulus and vickers hardness. - Materials Research, 2004, vol. 7, № 3, 483-491.

29. Zalavutdinov R., Novohatsky A., Gusev V. et al. Electron beam treatment of tungsten mock-ups. - In: 16th Intern. Conf. on Plasma-Facing Materials and Components for Fusion Applications (PFMC-2017). Neuss/Düsseldorf, Germany, 16-19 May, 2017.

30. Lassner E., Schubert W.-D. Tungsten. Properties, Chemistry, Technology ūof the Element, Alloys and Chemical Compounds. Kluwer Academic/Plenum Publishers, 1999. ISBN 0-306-45053-4.

31. Huber A. et al. Investigation of the impact on tungsten of transient heat loads applied by laser irradiation. - In: 4th Intern. Workshop PMIF 2013. Oak Ridge, TN, USA, Sept. 9-13 2013.

32. Linke J. et al. Perfomance of different tungsten grades under transient thermal loads. — Nucl. Fusion., 2011, vol. 51, p. 073017

33. Gusev V.K. et al. — Techn. Phys., 1999, vol. 44, p. 1054.

34. Burtseva T.A. et al. Carbon materials. — In: Proc. of 6th Intern. Workshop. Julich, Germany, 23-24 September 1993, p. 49.

35. Gorodetsky A.E. et al. — Fus. Eng. Des., 1998, vol. 43, p. 129.

36. Novokhatsky A.N. et al. Testing of mock-ups for a full tungsten divertor on Globus-M tokamak. — In: 25th IAEA Fusion Energy Conf. Saint Petersburg, Russia, 13-18 October 2014. MPT/P8-15; https://conferences.iaea.org/indico/contributionDisplay.py ?contribId=246\&sessionId=3 4\&confId=46.

37. Voronin A.V. et al. Experimental study of cyclic action of plasma on tungsten. - Technical Physics, 2016, vol. 61, № 3, p. 370-376; (C) Pleiades Publishing, Ltd., 2016. 


\section{AUTHORS}

Novokhatsky A.N. A.F. Ioffe Physical-Technical Institute of the Russian Academy of Sciences, Politekhnicheskaya ul. 26, 194021 St. Petersburg, Russia; A.Novokhatsky@mail.ioffe.ru

Gusev V.K. A.F. Ioffe Physical-Technical Institute of the Russian Academy of Sciences, Politekhnicheskaya ul. 26, 194021 St. Petersburg, Russia

Ber B.Ya. A.F. Ioffe Physical-Technical Institute of the Russian Academy of Sciences, Politekhnicheskaya ul. 26, 194021 St. Petersburg, Russia

Brunkov P.N. A.F. Ioffe Physical-Technical Institute of the Russian Academy of Sciences, Politekhnicheskaya ul. 26, 194021 St. Petersburg, Russia

Bukhovets V.L. A.N. Frumkin Institute of Physical Chemistry and Electrochemistry RAS, Leninsky prospect 31, 119071 Moscow, Russia

Gervash A.A. D.V. Efremov Scientific Research Institute of Electrophysical Apparatus, pos. Metallostroy, Doroga na Metallostroy 3, 196641 St. Petersburg, Russia

Gorodetsky A.E. A.N. Frumkin Institute of Physical Chemistry and Electrochemistry RAS, Leninsky prospect 31, 119071 Moscow, Russia; gorodetsky@ipc.rssi.ru

Grigoriev S.A. D.V. Efremov Scientific Research Institute of Electrophysical Apparatus, pos. Metallostroy, Doroga na Metallostroy 3, 196641 St. Petersburg, Russia

Kuznetsov V.E. D.V. Efremov Scientific Research Institute of Electrophysical Apparatus, pos. Metallostroy, Doroga na Metallostroy 3, 196641 St. Petersburg, Russia

Litunovsky N.V. D.V. Efremov Scientific Research Institute of Electrophysical Apparatus, pos. Metallostroy, Doroga na Metallostroy 3, 196641 St. Petersburg, Russia

Makhankov A.N. D.V. Efremov Scientific Research Institute of Electrophysical Apparatus, pos. Metallostroy, Doroga na Metallostroy 3, 196641 St. Petersburg, Russia

Mazul I.V. D.V. Efremov Scientific Research Institute of Electrophysical Apparatus, pos. Metallostroy, Doroga na Metallostroy 3, 196641 St. Petersburg, Russia

Mukhin E.E. A.F. Ioffe Physical-Technical Institute of the Russian Academy of Sciences, Politekhnicheskaya ul. 26, 194021 St. Petersburg, Russia

Petrov Yu.V. A.F. Ioffe Physical-Technical Institute of the Russian Academy of Sciences, Politekhnicheskaya ul. 26, 194021 St. Petersburg, Russia

Rybkina T.V. A.N. Frumkin Institute of Physical Chemistry and Electrochemistry RAS, Leninsky prospect 31, 119071 Moscow, Russia

Sakharov N.V. A.F. Ioffe Physical-Technical Institute of the Russian Academy of Sciences, Politekhnicheskaya ul. 26, 194021 St. Petersburg, Russia

Sokolov R.V. A.F. Ioffe Physical-Technical Institute of the Russian Academy of Sciences, Politekhnicheskaya ul. 26, 194021 St. Petersburg, Russia

Tanchuk V.N. D.V. Efremov Scientific Research Institute of Electrophysical Apparatus, pos. Metallostroy, Doroga na Metallostroy 3, 196641 St. Petersburg, Russia

Tolstyakov S.Yu. A.F. Ioffe Physical-Technical Institute of the Russian Academy of Sciences, Politekhnicheskaya ul. 26, 194021 St. Petersburg, Russia

Voronin A.V. A.F. Ioffe Physical-Technical Institute of the Russian Academy of Sciences, Politekhnicheskaya ul. 26, 194021 St. Petersburg, Russia

Zakharov A.P. A.N. Frumkin Institute of Physical Chemistry and Electrochemistry RAS, Leninsky prospect 31, 119071 Moscow, Russia

Zalavutdinov R.Kh. A.N. Frumkin Institute of Physical Chemistry and Electrochemistry RAS, Leninsky prospect 31, 119071 Moscow, Russia; rinadz@mail.ru 

Ser. Thermonuclear Fusion, 2017, vol.40, issue 4, pp. 14-24. 